\title{
Review on the study of health effects of some fermented foods consumed on Côte d'Ivoire
}

\author{
Mouroufie AKJ ${ }^{1 *}$, Eudes SKPAN ${ }^{2}$, Kouakou AC ${ }^{3}$, Kouakou EKV ${ }^{1}$, Kati-Coulibaly $S^{1}$ \\ 1 Laboratory of Nutrition and Pharmacology, Faculty of Biosciences, University Felix Houphouet-Boigny, Abidjan, Ivory Coast 22 \\ B.P. 582 Abidjan 22, Ivory Coast, Argentina 2 Laboratory of Pharmacodynamics and Biochemistry, Félix Houphouet Boigny \\ University, Ivory Coast 3 Nangui Abrogoua University Training and Research Unit in Food Science and Technology (UFR-STA) \\ Laboratory of Food Biotechnology and Microbiology.
}

\begin{abstract}
Traditionally produced starchy foods and fermented beverages contribute to the diet of people. The benefits of these fermented traditional foods for health and their nutritional quality are poorly known.

This review gives a synoptic view of some fermented foods consumed in Côte d'Ivoire. Several foods are fermented traditionally, including cereals (maize, millet and sorghum), tubers (cassava), fruits (cocoa beans), palm sap (bandji) and fish (Galeoides decadactylus, Oreochromis niloticus).

These fermented foods have varying qualities. Lactic acid bacteria are the main microorganisms of their fermentations. Beyond their nutritional quality, fermented foods and fermentation actors may have other "health effects". The survival capacity of lactic acid bacteria at the conditions encountered in the digestive tract and their effect on the maintenance of the integrity of the digestive tract are particularly interesting.

This review focuses on the benefits of fermented foods including nutritional aspects, health benefits and lactic microflora that occurs during spontaneous fermentations as well as their probiotic effects will also be examined.
\end{abstract}

Citation: Mouroufie AKJ, Eudes SKPAN, Kouakou AC, Kouakou EKV, Kati-Coulibaly (2018) Review on the study of health effects of some fermented foods consumed in Côte d'Ivoire, GJBAHS 7: 5.

Received: November 29, 2018; Accepted: December 15, 2018; Published: December 22, 2018

Copyright: $($ C2018 Mouroufie AKJ, et al. This is an open-access article distributed under the terms of the Creative Commons Attribution License, which permits unrestricted use, distribution, and reproduction in any medium, provided the original author and source are credited.

Competing interests: The authors have declared that no competing interests exist.

Sources of funding: No funding.

*Email: abojerome7@gmail.com

\section{Keywords:}

Fermentation, Micro-organisms, Fermented foods

\section{Introduction}

Fermentation of food, a method long used by many persons, was originally intended to improve the conservation of food and its nutritional and health quality $[1,2]$. In developing countries, fermentation is one of the most used technologies for food and conservation. It allows them to preserve and often improve the organoleptic and nutritional quality of food [3]. It is an interesting process in a context of sustainable development and improvement of food systems because it produces little effluent and requires little energy for its implementation [4].

Indeed, fermentation improves the digestibility of food. It makes the nutrients better assimilable. This fermentation plays an important role in the diet of the populations of West Africa. Like other countries in the sub-region, in Côte d'Ivoire, fermented products play a major role in the diet and health of populations. The majority of traditional fermented products consumed in Côte d'Ivoire are processed by the natural fermentation of tubers (cassava), fruit (cocoa beans), cereals (millet, sorghum, maize) and fish (adjuevan). Some can be used as weaning foods for infants [5]. 
Lactic fermentation is the most common, although acetic and alcoholic fermentations are encountered [6]. In this type of fermentation lactic acid bacteria are the dominant microorganisms. Their main functions are the production of organic acids and aromatic compounds as well as other effects such as yeast stimulation, inhibition of pathogenic microorganisms, improvement of nutritional quality and probiotic activity [7]. Some fermented foods contain live microorganisms, including probiotics, which may be beneficial for digestive health [8]. The number of living microorganisms in the intestine increases by the consumption of fermented foods. Hence the importance attached to fermented foods. This study aims to show some health effects of some fermented foods consumed in Côte d'Ivoire.

\section{Fermentation}

Fermentation is a natural phenomenon, occurring during the decomposition of organic matter. Indeed, it is a biochemical reaction that consists of releasing energy from an organic substrate under the action of microbial enzymes and rejecting products. The fermentation microorganisms are divided into three groups: bacteria, molds and yeasts [9]. Four types of fermentations are found in the food field. Lactic, alcoholic, and propionic fermentation use sugars to form lactic acid, ethanol, and carbon dioxide, respectively, and propionate. Acetic ferments, on the other hand, use ethanol to produce acetic acid.

\section{Lactic fermentation}

In aerobic living organisms, ATP, which is the major form of energy directly usable by the cell, is produced during metabolic reactions including the oxidation of sugars, especially glucose, during glycolysis [10]. Under anaerobic conditions, the proton acceptor molecule of the reduced cofactors is pyruvic acid, which is reduced to lactic acid [11]. The latter allows glycolysis to persist under anaerobic conditions, which leads to the production of 2 molecules of ATP against 36 in the presence of oxygen.

\section{Alcoholic fermentation}

During the alcoholic fermentation, several changes can appear: a release of carbon dioxide, an increase in temperature and color, a change of smell and flavor, a decrease in the density (transformation of sugar into alcohol) and increased volumes.

\section{Acetic fermentation}

Acetic acid comes from the oxidation of alcohol by the oxygen of the air. Wine, beer, cider and, in general, all fermented liquids become tart in contact with the air.

The simplified acetic fermentation reaction is:

$$
\begin{aligned}
& \mathrm{CH}_{3}-\mathrm{CH}_{2}-\mathrm{OH}+\mathrm{O}_{2} \rightarrow \mathrm{CH}_{3}-\mathrm{COOH}+\mathrm{H}_{2} \mathrm{O}+ \\
& \text { Energy }
\end{aligned}
$$

\section{The propionic fermentation}

Propionic fermentation uses a wide variety of substrates: sugars, glycerol, lactic acid, malic acid. Propionic fermentation with lactic acid substrate plays a major role in cheese making. The bacteria that produce it are the bacteria of the genus Propionibacterium. This fermentation leads to the formation of propionate, acetate and $\mathrm{CO}_{2}$, from glucose or lactate, and takes place anaerobically.

\section{Some Fermented Foods Eaten in Côte d'Ivoire}

\section{The tubers}

Some fermented products in Ivory Coast are grouped in tubers ('attiéké', 'placali', 'attoupkou'). The cassava root (Manihot esculenta Crantz) is the fourth crop for its contribution to the world's population after rice, wheat and maize [12]. Many studies have shown that lactic acid bacteria are involved in cassava fermentation (Table 1) [13-15] and contribute to the elaboration of the organoleptic characteristics of the finished product. Lactic acid bacteria are the dominant microorganisms in cassava pulp for the production of "attiéké" during fermentation [15]. The identification of the microorganism species during the production of attiéké showed the presence of Leuconostoc mesenteroides subsp. mesenteroides, Lactobacillus 
salivarius and L. delbrueckii subsp. delbrueckii, as

well as L. fermentum and L. confusus [16].

Table 1: Comparative tables of description of fermented product methodologies.

\begin{tabular}{lll}
\hline Raw material & Description of fermentation methodologies and products. & $\begin{array}{l}\text { Finished products } \\
\text { and names }\end{array}$ \\
\hline
\end{tabular}

\section{Alcoholic drink}

Sorghum or The traditional processing of 'tchapalo' is complex and involves milling of malted 'Tchapalo

Maize sorghum, mashing, acidification, cooking, cooling and the alcoholic fermentation of the final wort by dried yeast taken from a previous fermentation.

Sap of palm tree Bandji' is an alcoholic beverage produced from the sap of palm tree, which is tapped and Badji allowed to undergo spontaneous fermentation. The process of tapping palm wine involves first felling or cutting down the tree, leaving the felled tree for a period of about 2 weeks for the sap to concentrate, followed by tapping for up to 8 weeks. The sap, which is originally sweet, ferments within 2-3 h and develops a stronger alcoholic taste and smell with time.

\section{Fermented products from fruits}

Cocoa pod Cocoa fermentation is a key step in the technological transformation of cocoa into 'Fermented cocoa chocolate, because the highly bitter, astringent unfermented cocoa beans lack the full beans' chocolate flavor. The fermentation of cocoa beans is therefore the first step of the chocolate-making process, which consists of a natural, microbial fermentation of the pectinaceous pulp surrounding the seeds of the tree Theobroma cacao.

\section{Foods made from cassava root}

Cassava root Attiéké' is a flavorful starchy ingredient, produced from fermented cassava root. The Attiéké fermented and pressed pulp is taken from the bags and squeezed through a sieve to obtain granules that are sundried and then cleaned to remove fibres and waste. The dried granules are steamed to produce 'attiéké', which is sold in small plastic bags as a ready-to-eat food.
Cassava root To produce 'attoupkou' the fermented cassava mash is first squeezed to remove as much Attoupkou water as possible. Then it is sun-dried into granular flour which is steam-cooked in special clay cooker for 45 minutes into a large cake.
Cassava root To produce 'bêdêcouman' the fermented cassava mash is cooked, shelled and shaped into 'Bêdêcouman' Tomatococcus danielli sheets commonly called 'attiéké leaves'
Cassava root The fermented and dehydrated mass of cassava is cooked in water until a sugary and Placali transparent paste is obtained.

\section{Foods made from rice, maize or millet}

Mil / Rice 'Baca' is a popular traditional fermented gruel obtained from millet, maize or rice usually Baca consumed in Côte d'Ivoire as breakfast by adults and as complementary food by young children. The millet or maize flour is sieved, mixed with a quantity of water and rolled by hand to obtain a granulated product. The granulated product could be left to ferment overnight at ambient temperature. The millet or maize granulated product (fermented or not) and rice flour are added.

Maize 
Maize/rice

'Wômi is a traditional fried cake made from sorghum, maize or millet flour. To produce Womi

'wômi', the cereal flour is added to boiling water and cooked to gelatinization and allowed

to cool before mixing with raw flour. The resulting batter inoculated or not with baker's yeast is allowed to ferment overnight.

Food condiment made from fish

Fish
'Adjuevan' is a traditional Ivorian naturally fermented fish prepared from the Atlantic Adjuevan
bumper Chloroscombrus chrysurus or the sea fish Galeoides decadactylus. It is produced through a spontaneous and uncontrolled fermentation and by using a high amount of salt. For traditional 'adjuevan' production, the fresh fish is scaled, gutted, washed and left overnight before the seemingly deteriorated fish is treated with salt and allowed to ferment for 6 hours to 8 days.

In Côte d'Ivoire, Attiéké, 'placali', gari and 'Attoupkou' are derived from the transformation of the cassava root. The cassava paste used goes through a fermentation process. For this to happen quickly and well, it is mixed with an inoculum or ferment which is actually a small amount of previously fermented cassava. After this addition, the dough is kept for two days. This fermentation is necessary because it allows to eliminate a large part of the hydrocyanic acid present naturally in cassava. "Attiéké", "attoukpou" and "placali" are potential energy sources in the diet of Ivorians [17].

'Attoupkou' is the third cassava product consumed in Côte d'Ivoire after 'attiéké' and 'placali' [16]. Attiéké 'is a starch-rich ingredient produced from fermented cassava root [16].'In Ivory Coast, "placali" is commonly consumed and is the second most popular cassava product after "attiéké" [12].The fermented and dehydrated mass of cassava is cooked in water until a sweet and transparent paste is obtained.

The 'Bêdêcouman' is very popular and mainly produced by the populations of southeastern Côte d'Ivoire by the Abouré and N'Zima ethnic groups. To obtain the "bêdêcouman", the mashed manioc is fermented and cooked. The mineral content of the three dishes is very low $[18,19]$. However, major minerals are present in attiéké ',' placali 'and attoupkou' like Sodium ( $\mathrm{Na}$ ) Phosphorus (K), Calcium (Ca), Potassium (P), Magnesium $(\mathrm{Mg})$ and chlorine $(\mathrm{Cl})$, with a high $\mathrm{K}$ [20]. Magnesium $(\mathrm{Mg})$ is involved in bone development, protein building, enzymatic actions, muscle contraction, dental health and the functioning of the immune system.

Copper $(\mathrm{Cu})$ is necessary for the formation of hemoglobin and collagen (a protein used to structure and repair tissue) in the body. Several copper-containing enzymes also contribute to the body's defense against free radicals. Phosphorus (P) is the second most abundant mineral in the body after calcium. It plays a vital role in the formation and maintenance of healthy bones and teeth. In addition, it participates among other things in the growth and regeneration of tissues and helps to maintain the $\mathrm{pH}$ of the blood. Chlorine $(\mathrm{Cl})$, for its part, allows sodium, the metabolism of water and consequently the regulation of water retention in the human body. It also plays an important role for the digestive system.

Calcium $(\mathrm{Ca})$ is important for blood clotting, the functioning of the brain and the nervous system, but also for muscle contraction. This is why it plays a vital role in muscle growth. Potassium or vitamin K is essential for the blood system, to allow good coagulation and good healing in case of injury. In addition to the main function of assisting blood clotting, vitamin $\mathrm{K}$, and especially $\mathrm{K} 1$, plays an important role in the process of growth and bone fortification. Helps to fix calcium in the bones and fight against osteoporosis, which affects most women during menopause. The trace elements found in dishes like $\mathrm{Si}, \mathrm{Cu}, \mathrm{S}$ and $\mathrm{Cl}$, the values of which do not reach the food toxicity threshold. The three dishes have organoleptic characteristics that allow them to be well appreciated by consumers. In addition, "attiéké", "attoukpou" and "placali" are foods that are very rich in energy and carbohydrates [20].

\section{Fermented cereal products}

Cereals are often used to produce beverages such as sweet must and tchapalo [21]. Chapalo is obtained from the alcoholic fermentation of sweet wort from sorghum malt. It can also be produced from corn 
malt or millet. This drink is also characterized by a short shelf life (3 days) and a quality that varies from one production to another [21]. Chapalo is highly prized by the Ivorian population $[22,23]$. This drink has nutritional values that help improve the diet of consuming populations. In addition, therapeutic virtues are attributed to it because of its laxative, antimalarial and anti-haemorrhoidal properties [24]. The microorganisms found in fermented cereals for the production of tachapalo and Doklu are L. plantarum, L. fermentum, $L$. cellobiosis, L. brevis, L. coprophilus, Enterococus $s p$, Pediococus sp., Leuconostoc sp. Pediococcus pentosaceus, $P$. acidilactici, L. fermentum, $W$. cibaria, L. fermentum [23-26]. 'Doklu' is produced after spontaneous fermentation of maize paste and consumed by the populations of southern and south-eastern Côte d'Ivoire [25]. After washing, whole corn kernels are soaked in water for 2 or 3 days, crushed, mixed in water and allowed to ferment spontaneously for 24 to 72 hours (Table 1).

'Baca' is a traditional fermented food made from millet, which is consumed in Côte d'Ivoire as breakfast by adults and as a supplementary food for young children [26,27]. The millet granule or corn flour is sieved, mixed with a quantity of water and rolled by hand to obtain a granulated product that can be fermented overnight at room temperature. 'Wômi is a traditional fried cake made from sorghum, corn or millet flour. The cereal flour is added to boiling water and cooked by gelatinization and allowed to cool before being mixed with raw flour. The resulting paste inoculated or not with baker's yeast is left to ferment overnight. It is consumed by all age groups and serves as a breakfast and snack [16]. Grain products undergo lactic fermentation and are biochemical and nutritional.

The biochemical composition of millet brings it closer to sorghum. Starch contents are slightly lower than those of sorghum, while the protein and lipid content are higher than that of sorghum and most other cereals (maize, sorghum, rice, etc.).

Some millet-based foods have been studied for monitoring the fermentation microflora during the manufacturing process. Fermentation results in an increase in microbial biomass that produces a diversity of primary, secondary, and protein metabolites in the food matrix. Fermentation of millet leads to a decrease in oligosaccharides and indigestible polysaccharides lead to an increase in lysine content [28]. Likewise, an increase in methionine and tryptophan content has been observed during maize fermentation [29]. Some amino acids can be synthesized and the bioavailability of increased $\mathrm{B}$ vitamins increased [30]. Fermentation promotes optimal $\mathrm{pH}$ for the enzymatic degradation of phytates that are present in cereals in forms complexed with proteins and certain minerals such as iron, zinc and magnesium [31]. A reduction in phytates can increase the amount of soluble iron, zinc and calcium. In addition, lactic fermentation results in a very highly positive effect on the availability of iron and phosphorus, with a decrease in phytate content in these fermented products [32]. Antinutritional factors such as phytates and tannins are among the constituents of the grain walls of cereals. Antinutritional factors contribute to malnutrition and reduced growth rate and are responsible for low protein digestibility, reduced bioavailability of mineral elements such as phosphorus, calcium, magnesium, iron and zinc and the reduction of certain enzymatic activities such as trypsin, alphaamylase and beta-galactosidase [33]. The composition of the sorghum grain used for the production of tachapalo depends on the variety and cultural locations. According to [34], sorghum is essentially starch, its protein content is almost equal to and comparable to that of corn and wheat, its fat content is higher than that of wheat but lower than that of corn. Sorghum is also characterized by its high fiber content and poor digestibility of nutrients. It contains detectable amounts of vitamins D, E and K. Sorghum also contains minerals such as phosphorus, iron, zinc, potassium and copper [35]. Sorghum contains anti-nutritional factors such as tannins and phytates. To improve its nutritional quality, methods of germination, fermentation and cooking are used [36].

\section{Fermented fish 'Adjuevan'}

'Adjuevan' is a naturally fermented Ivorian traditional fish made from Chloroscombrus chrysurus or Galeoides decadactylus sea fish $[37,38]$. It is produced by spontaneous and uncontrolled fermentation and using a large amount of salt (Table 1). The final product is highly concentrated in salt with a strong smell used as a condiment to season sauces. Several studies have shown the presence of Leuconostoc lactis, 
Lactobacillus, fermentum, Pediococcus sp., Streptococcus sp., Lactococcus garviae, S. difficilis in Adjuevan [39]. Fermented fish are beneficial to human health because they contain dipeptides that lower blood pressure and induce insulin secretion [40]. Analysis of the free amino acids of fermented fish has shown the presence of many essential free amino acids such as arginine, tryptophan, histidine, isoleucine, lysine, threonine, methionine, phenylalanine, leucine and valine with significant amounts. Given the essential amino acid composition, fermented fish "adjuevan" is a product of good nutritional quality and can be used as an alternative source of protein for people in developing countries. The presence of several omega-3 and omega-6 fatty acids has been observed in fermented adjuevan. Studies by [39] on fermented fish (adjuevan) indicate that the lipids of adjuevan contain large amounts of monounsaturated fatty acids and polyunsaturated fatty acids. Adjuevan is rich in omega-3s such as glutamic acid, leucine, lysine, isoleucine, valine and omega-3 polyunsaturated fatty acids (PUFAs) such as eicosapentaenoic acid (EPA) and lactic acid. docosahexaenoic acid (DHA). For example, fermented fish sauces are beneficial to human health because they contain dipeptides that lower blood pressure and induce insulin secretion [40]. In addition, lactic fermentation results in a very highly positive effect on the availability of iron and phosphorus, with a decrease in the phytate content in these fermented products [32].

\section{Fermented palm wine}

Palm wine is a drink obtained from the fermentation of palm leaves (Elaeis guineensis) by indigenous microbes. Palm wine is obtained from the palm tree (E. guineensis) [41]. It undergoes spontaneous fermentation, which promotes the proliferation of microorganisms because of its nutritional content (Table 1). The presence of microbial populations in this beverage is of paramount importance to public health given the specific role of organisms [42]. The presence of a large population of lactic acid bacteria could have a beneficial effect on the health of the consumer and thus increase the interest of this drink [41]. The sap of the palm tree is subjected to a spontaneous fermentation that promotes the proliferation of yeast species for the transformation of the sweet substrate into an alcoholic beverage containing important nutritional components, including amino acids, proteins, vitamins and sugars [43]. Consuming fermented foods daily may be equivalent to introducing new, albeit transient, microorganisms into the native gut microbiota [44]. The action of lactic acid bacteria during fermentation also has an impact on the nutritional value of fermented products in Côte d'Ivoire.

\section{The fruits}

Cocoa beans are usually fermented in Côte d'Ivoire in heaps on small farms or in wooden crates on large, non-turning farms [45]. The predominant fermentation process practiced in Ivory Coast generally lasts between 4 and 5 days. L. fermentum, Leu. pseudomesenteroides are found in fermented cocoa beans [46,47]. are involved in the fermentation process of cocoa beans. Yeasts and molds, acetic and lactic acid bacteria, Bacillus are involved in the fermentation process of cocoa beans [48]. The lactic bacteria found are L. fermentum and Leu. Pseudomesenteroides [46,47]. Cocoa beans are rich in nutrients (Phosphorus, Magnesium, Iron, Zinc, Manganese, Copper, Theobromine, Phenylethylamine, Flavonoids, Polyphenols, Catechins, Tannins), anti-oxidants. They act on the health notably on the cardiovascular, the regulation of the blood pressure and cholesterol, improvement of the cognitive capacities, reduction of the stress, reinforcement of the immune system. The cocoa beans after fermentation for several days preserve their taste and nutritional qualities. The components of the cocoa bean are rich in minerals (magnesium, iron, zinc, potassium, copper and selenium), vitamins (A, B, C, D, E).

\section{Probiotic Properties of Lactic Acid Bacteria in Fermented Foods}

According to the Food and Agricultural Organization (FAO) and the World Health Organization (WHO), probiotics are living microorganisms that, when consumed in sufficient quantities in the diet, have a beneficial effect on the health of the host $[48,49]$. The ability to be active in the targeted action site and to provide a real benefit to the consumer therefore determines the true effectiveness of a probiotic. Strains of probiotic lactic acid bacteria are derived from fermented foods and belong mainly to the genera Lactobacillus and Bifidobacterium. 
Indeed, these probiotic microorganisms have beneficial effects on the health of the consumer, including the improvement of lactose digestion, the equilibration of intestinal microflora. In addition, these strains decrease the risk of food allergy, stimulation and modulation of the immune system; as well as improving inflammatory bowel disease and preventing cancer.

Microorganisms ingested alive from fermented foods will play on the health of humans. In human nutrition, many studies focus either on the effect of fermentation and fermentation microorganisms on the nutritional quality of the [50], or on the effect of food, on health [51], or the role of gut microbiota in human health [52]. Bacteria, whether they come from the food or reside in our digestive system, are therefore actively involved in our nutritional status and state of health.

\section{Safety of Fermented Foods}

During fermentation lactic acid bacteria produce many natural antimicrobial compounds, such as lactic acid, acetic acid, formic acid, and caproic acid, carbon dioxide, hydrogen peroxide, diacetyl, ethanol and bacteriocins. Indeed, the production of organic acids and antimicrobial compounds during fermentation leads to a decrease in $\mathrm{pH}$ that makes the presence of pathogenic bacteria.

The action of lactic acid bacteria during fermentation would allow the elimination of toxic compounds in the fermented food. In addition, studies have shown that adjuevan has a low biogenic amine content well below international standards, which proves the lack of toxicity of adjuean at the end of production. Therefore, adjuevan can be eaten, especially for its good nutritional quality just after fermentation [38]. Fermentation, when controlled, using starter cultures and in clean manufacturing environments, fermentation allows the production of foods of sanitary quality, nutritional and organoleptic regular.

\section{Conclusion}

The fermentation of starchy products and beverages leads to an increase in the protein content, in free amino acids, in vitamins. It facilitates digestion and increases the fiber content, and contributes to a higher bioavailability of mineral elements. The presence of lactic acid bacteria and yeasts with high probiotic potential which produce acidic and bactericidal compounds improves the sanitary quality of the products and guarantees the health of the consumer. During fermentation, the action of lactic acid bacteria and yeasts increases the digestibility of starch and proteins [52].

The study of these foods has provided insight into the beneficial microbial interactions and health effects of fermented foods. Fermented foods can be a source of beneficial probiotic microorganisms when the product is consumed without a cooking step after fermentation, thus keeping microorganisms alive and able to exert their probiotic effect. However, very few studies have focused on the health effect of fermented foods in Côte d'Ivoire. Given the burden of malnutrition, the valorization of traditional fermented foods is necessary.

\section{References}

1. Gotcheva V, Pandiella SS, Angelov A, Roshkova Z, Webb C. Monitoring the fermentation of the traditional Bulgarian beverage boza. Int $\mathrm{J}$ Food Sci Technol. 2001;36:129-134.

2. Marie-Claire F, Stutin G. Fermented foods, health food. 2016.

3. Kalui CM, Mathara JM, Kutima PM. Probiotic potential of spontaneously fermented cereal foods: a review. Afr J Biotechnol. 2010;9:2490-2498.

4. Humblot C. The food-microbiotic-host relationship University of Montpellier. 2015;75.

5. Yao Soro AA, Kouakou B, Koffi-Nevry R, Koffi MD. Microbiology of ivorian fermented products: A review by the Journal of Agriculture and Food Science. 2013;1.

6. Beuchat LR. Traditional fermented foods, in: Doyle MP, Beuchat LR, Montville TJ (Edn), Food Microbiologyfundamentals and frontiers. ASM press, Washington DC. 1997;629-648.

7. Yao AA, Eg Ounlety M, Kouame LP, Thonart P. Lactic acid bacteria in starchy and fermented foods or beverages from West Africa: their current use. Ann Med Vet. 2009; 153:54-65.

8. Marco ML, Heeney D, Binda S, Cifelli CJ, Cotter PD. Health benefits of fermented foods: microbiota and beyond. Current Opinion in Biotechnology. 2017;44:94-102.

9. Camus G. Lactic fermentation and its use in making yoghurt. 2011.

10. FAO. Fermented cereal, a global perspective, 1999, Available at: http://www.fao.org/ (accessed May, 23Asian Online Journals (www.ajouronline.com) 47th, 2013).

11. Koko CA, Konan A, Tetchi F, Assidjo E, Amani G. Quality of fermented cassava flour processed into placali, Intern J Bio Chem Sci. 2012;6:415-420. 
12. Djeni NT, Kouamé KA, Bouatenin MKJ-P, N'Guessan KF, Dje KM. Processus de production de l'attiéké" en Côte d'Ivoire : les nouvelles tendances, les mises à jour et les effets sur la qualité et la préférence du mets. International Journal of Advanced Research. 2014;2:644-653.

13. Bouatenin MKJ-P, Djéni NT, Aka $\mathrm{S}$, Brou K, Djè KM. The contribution of microorganisms to the fermentation of cassava dough during Attiéké processing in Côte d'Ivoire. Food. 2012;6:58-64.

14. Assanvo JB, Agbo GN, Behi YEN, Coulin P, Farah S. Microflora of traditional starter made from cassava for " attieke " production in Dabou (Ivory Coast). Food Control. 2006;17:37-41.

15. Amani NG, Kamenan A. Nutritional potentialities and traditional process of starchy crops in the Côte d'Ivoire. Proceedings of the 2nd international workshop on foodbased approaches for a healthy nutrition in West Africa: The role of food technologists and nutritionists, Ouagadougou. 2003;152.

16. Sahoré DA, Nemlin GJ, Kamenan A. Changes in nutritional properties of Yam (Dioscorea spp), plantain (Musa spp) and cassava (Manihot esculenta) during storage. Tropical Sciences. 2007:47:81-88.

17. Gbané M, Coulibaly A, Niaba KPV, Adou M. Composition physico-chimique et sanitaire de deux mets de rue (le plat d'attiéké et le garbe) vendus à Abidjan (Côte d'Ivoire). Afrique biomedicale. $2012 ; 17: 3$.

18. Yéboué, et al. Valeur nutritive et propriétés organoleptiques de l' attiéké, de l'attoukpou et du placali, trois mets à base de manioc, couramment consommés en Côte d'Ivoire . J Appl Biosci. 2017;113:11184-11191.

19. Kouame KB, Koko AC, Masse D, Assidjo NE. Batch fermentation process of sorghum wort modeling by artificial neural network. European Scientific Journal. 2015;11:75-93.

20. Dje MK, N'Guessan KF, Djeni TN, Dadie TA. Biochemical changes during alcoholic fermentation in the production of tchapalo, a traditional sorghum beer. Int $\mathrm{J}$ Food Eng. 2008;4:2.

21. N'Guessan FK, N'diri DY, Camara F, Djè MK Saccharomyces cerevisiae and Candida tropicalis as starter cultures for the alcoholic fermentation of tchapalo, a traditional sorghum beer. World J Microbiol Biotechnol 2010;26:693-699.

22. Aka S, Dje KM, Fokou G, Doumbia M, Ahoussi JM. Production and consumption of tchapalo in Abidjan: Typology of brewers and consumers. European Scientific Journal. 2017;13:1857-7881.

23. Assohoun MCN, Jeni NT, N'Guessan KF, Koussemon M Preliminary study on antimicrobial properties of lactic acid bacteria involved in dough fermentation during doklu processing in Ivory Coast Food. 2012;6:65-70.

24. AKA S, Konan G, Fokou G, Djè K M, Bonfoh B. Review on African traditional cereal beverages. American Journal of Research Communication. 2014:2:103-153.

25. Brou K, Gbogouri A, Ocho AL, Jeni NT, Kone Y. Assessment of some chemical and nutritional properties of maize, rice and millet grains and their weaning muses. Pakistan Journal of Nutrition. 2008;7:721-725.
26. Hamad AM, Fields ML. "Lysine of germinated and fermented cereals." Journal of Food Science. 1979;44:456-459.

27. Nanson NJ, Fields M. "Influence of temperature of fermentation on the nutritive value of fermented corneal lactic acid." Journal of Food Science. 1984;49:958-959.

28. Blandino A, Aseeri MA, Pandiella S, Cantero D, Webb C. "Cereal-based fermented foods and beverages." Food research international. 2003;36:527-543.

29. Harland BF, Morris ER. "Phytate: a good or bad food component?" Nutrition Research 1995;15:733-754.

30. Raimbiault M. "Importance of lactic acid bacteria in cassava fermentations." Agbor Egbe, Brauman, Griffon, Treche. Food processing of cassava. Ed Orstom, Paris. 1995;747.

31. Nyanzi R, Jooste PJ. Cereal-based functional foods INTECH. 2012;161-195.

32. FAO. Sorghum and millets in human nutrition. FAO collection (Rome). 1995.

33. Glew RH, Vanderjagt DJ, Lockett C, Grivetti LE, Smith GC, et al. Amino acid, fatty acid and mineral composition of 24 indigenous plants of Burkina Faso. J Food Comp Anal. 1997;10:205-217.

34. Dicko MH, Gruppen H, Zouzouho OC, Traore AS, Voragen AGJ, et al. Sorghum grain as human food in Africa: relevance of content of starch and amylase activities. Afr J Biotechnol. 2006;5:384-395.

35. Koffi-Nevry R, Koussémon M. Microbiological Composition, Processing and Consumer's Characteristics of Adjuevan, Traditional Ivorian Fermented Fish, Tropicultura. 2012;30:9-14.

36. Kouakou AC, Cisse M, Kossonou E, Brou KD, Dje KM, et al. Identification of yeasts associated with the fermented fish, adjunct, of Ivory Coast by using the molecular technique of PCR-denaturing gradient gel electrophoresis (DGGE). African Journal of Microbiology Research. 2005;6:4138-4145.

37. Toshiaki IJH, Aita DQ, Maruyama S. Angiosteusis I. Conventing enzyme inhibitory activity and insulin secretion stimulation. Journal of Biosciences and Bioengineering. 2005;96:496-499.

38. Kouakou AC, Nguessan KF, Dadier AT, Djè KM, Montet D. Application of culture dependent methods and cultureindependent methods (DGGE analysis) to study Lactic acid bacteria ecology of Ivorian fermented fish Adjuevan. Challenges of Modern Technology. 2012;3:50-56.

39. Karamoko D, Djeni NT, N'guessan KF, Bouatenin KMJ-P, Dje KM. The Biochemical and Microbiological Quality of Food Sampling and Production of Food Control. Food Control. 2012;26:504-551.

40. Nwachukwu E, Achi OK, Ijeoma IO. Lactic acid bacteria in fermentation of cereals for the production of indigenous Nigerian foods. Afr J Food Sci Technol. 2010;1:021-026.

41. Okafor N. Palm Wine Yeasts from Parts of Nigeria. Journal of the Science of Food and Agriculture. 1972;23:1399-1407.

42. Ple'C, Breton J, Daniel C, Foligne' B. Maintaining gut ecosystems for health: are the food transitory bugs 
stowaways or part of the crew? Int J Food Microbiol. 2015;213:139-143.

43. Tagro SG, Konan YM, Koffi-Nevry R, N'Dri DY, Manizan NP. Enumeration and identification of main fungal isolates and evaluation of fermentation's degree of ivorian raw cocoa beans, Australian Journal of Basic and Applied Science Research. 2007;1:479-486.

44. Papalexandratou Z, Camu N, Falony G, De Vuyst. Bacterial species diversity of spontaneous cocoa bean fermentations in Ivory Coast and Brazil, Food Microbiology. 2011;28:964-973.

45. Tagro SG, N'Dri D, Yao, Manizan NP, Nevry KR, Louis BK, Yao MK, Comparison of the degree of fermentation and fungal profiles of raw cocoa beans sourced from three Ivorian main producing regions, African Journal of Food Science, 2008;2:112-118..

46. Ban KL, Ouattara GH, Karou TG, Tagro GS, Nemlin JG, Diopoh JK. Impacts of cocoa fermentation on the growth of microbial flora and the quality of marketable beans. African Agronomy 2013;25:159-170 .

47. FAO, 2001. Health and nutrition properties of probiotics in food including powder milk with live lactic acid bacteria, in: Probiotics, F.W.E.C.o.E.o.H.a.N.P.o. (Ed.), Food including Powder Milk with Live Lactic Acid Bacteria. FAO WHO, Cordoba, Argentina, p. 85

48. Capozzi V, Russo P, Duenas MT, Lopez P, Spano G. Lactic acid bacteria producing B-group vitamins: a great potential for functional cereals products. Applied Microbiology and Biotechnology 2012;96:1383-1394.

49. Roberfroid M, Gibson GR, Hoyles L, McCartney AL, Rastall R, Rowland I, et al. Prebiotic effects: metabolic and health benefits. Br J Nutr 104 Suppl 2, 2010;S1-63.

50. van Baarlen $\mathrm{P}$, Kleerebezem M, Wells JM. Omics approaches to study hostmicrobiota interactions. Current Opinion in Microbiology 2013;16:270-277. 